Volume and Issues Obtainable at Center for Sustainability Research and Consultancy
www.globalcsrc.org
Journal of Business and Social Review in Emerging Economies
ISSN: 2519-089X; (Online) 2519-0326
Volume 2: Issue 1 June 2016
CSRᄃ

\title{
Linking Work Environment, Team and Co-worker Relationship and Organization Well-being in Increasing Employee Engagement: A Conceptual Perspective
}

\section{${ }^{1 *}$ Athifah Najwani Shahidan, ${ }^{2}$ Siti Norasyikin Abdul Hamid, ${ }^{3}$ Bidayatul Akmal Mustafa Kamil, ${ }^{4}$ Shamsul Huda Abd. Rani, ${ }^{5}$ Azelin Aziz, ${ }^{6}$ Hazlinda Hassan}

\footnotetext{
${ }^{1}$ Othman Yeop Abdullah Graduate School of Business, Universiti Utara Malaysia athifah2409@ gmail.com

${ }^{2}$ School of Business Management, Universiti Utara Malaysia norasyikin@uum.edu.my

${ }^{3}$ School of Business Management, Universiti Utara Malaysia bidayatul@uum.edu.my

${ }^{4}$ School of Business Management, Universiti Utara Malaysia shuda@uum.edu.my

${ }^{5}$ School of Business Management, Universiti Utara Malaysia azelin@uum.edu.my

${ }^{6}$ School of Business Management, Universiti Utara Malaysia hazlinda@uum.edu.my
}

\begin{tabular}{l} 
ARTICLE DETAILS \\
\hline History \\
Revised Format: May 20 \\
Available Online: June 2 \\
\\
\hline Keywords \\
Employee engagement \\
Work environment \\
Team and co-worker \\
relationship \\
Organization well-being
\end{tabular}

JEL Classification:

J20,J21,J29

\begin{abstract}
Purpose - The purpose of this paper is to propose a conceptual framework on the key determinant of employee engagement. This paper is designed to study the three determinants that will impact on employee engagement. Three key determinants will be used as independent variables which are work environment, team and co-worker relationship, and organization wellbeing. Employee engagement acts as a dependent variable.

Methodology - This is a causal study that has used qualitative exploratory methodology to draw propositions about the phenomenon under study.

Findings - The findings of the study that supported by The Social Exchange Theory (SET) and The Leader-Member Exchange (LMX) were expected to produce significant relationship between work environment, team and co-worker relationship and organization well-being on employee engagement.
\end{abstract}

Practical implication - A deep focus should be given to the factors that can enhance work environment, team and co-worker relationship as well as providing supportive organizational well-being to ensure the employees in their organization is fully engaged.

Social implication - The determinant of employee engagement will promote a healthy and positive working environment that can contribute to positive and healthy life in social community.

(C) 2016 The authors, under a Creative Commons AttributionNonCommercial 4.0

*Corresponding author's email address: athifah2409@gmail.com

Recommended citation: Shahidan, N.A. Hamid, A.N. Kamil, M.A.B. Rani, A.H.S.Aziz, A. Hasan, H. (2016). Linking Work Environment, Team and Co-worker Relationship and Organization Well-being in Increasing Employee Engagement: A Conceptual Perspective. Journal of Business and Social Review in Emerging Economies, 2 (I) 21-30. DOI: 


\section{Introduction}

In this era, employee engagement has become a famous topic of discussion. It had been an important and eye-catching subject to consultation firms and among many popular media business. This is because of the rising number of studies that has been trying to extend the concept of employee engagement to work, job and organisation engagement (Welch, 2011) as it is also reported to influence various positive work outcomes (Vincent-Höper et al., 2012; Karatepe, 2013 and Harter et al., 2002).

Kahn (1990) was the first individual who determined work engagement as the "harnessing of organisational members' selves to their work roles". In addition he also states that engagement must come from the people who are being employed and is able to express it physically, cognitively, and emotionally to perform in any given or voluntary performances. In line with this, Shuck and Wollard (2010) also recently defined the term employee engagement as "an individual employee's cognitive, emotional, and behavioral state directed toward desired organisational outcomes".

Employee engagement is one of the key determinants fostering high levels of employee performance, as it is constantly shown in a number of studies (Macey et al., 2009; Mone \& London, 2010; Gorgievski et al., 2010; Christian et al., 2011; Chughtai \& Buckley, 2011). To become successful and competitive in the business area, an organisation should put more weight on employee engagement issues as to having a high level of engaged employees were reported to produce good business performance even in the turbulence economic (Kular et al., 2008; Harter et al., 2002; Shuck \& Wollard, 2010). Organisations which are faced with production decrease that has been resulted from global economy turbulence would still survive in the industry as engaged employees would continually perform their roles. They would be engaged with their jobs which will subsequently help the organisation to maintain and continue their operations. Thus, this shows that employees' engagement is an important element that is needed by the company, especially during any encounter with an economic turbulence.

Even though there has been increasing number of studies which investigates employee engagement, researchers have realized that academic researches lack practitioner developments (Macey \& Schneider, 2008; Robinson et al., 2004). Since the understanding of employee engagement is a fundamental element to organisational performance, there is a need to study the antecedent variables that has a direct impact to employee engagement.

\subsection{Problem Statement}

The real understanding of impact on the employee engagement is one of the fundamental elements towards an employee's performance. Hooper (2006) who is a well-known Australian researcher stated that the average Australian economy loses about $\$ 31$ billion yearly due to the issue of employees' disengagement and resignation from jobs. In addition, North Shore Health System has been invested in employee training and development for about $\$ 10$ million a year to encourage and train employees. This is substantial with hopes that this initiative can increase engagement levels among the employees within their firm (States, 2008). As a result, this action has given a positive outcome by decreasing for about 96 per cent of annual retention rate, increased in its customer satisfaction, as well as increased in profit (State, 2008).

Schaufeli and Bakker (2004) found that organizations that are able to engage with their employees are likely to have a stronger attachment to the organisation. Thus, engaged employees will have a lower intention to quit compared to the disengaged employees. Employee engagement has not only impacted 
employees' performance, but also gives an impact to turnover of employees.

Since the year 2000, a lot of papers have been published pertaining to employee engagement. Most of the published papers focused on the different definition of employee engagement. However, there are still little empirical researches that focus on factors to predict employee engagement. In addition, despite the recognisable importance of engagement (Kamet al., 2012; Macey et al., 2009; Shuck and Wollard, 2010), it appears to be a lack of consensus over the antecedents and outcomes of the construct. (Sowath Rana et al., 2014).

Thus, to fill the gap of knowledge about the antecedents of employee engagement, this study seem to be relevant to conduct as well as help to overcome the problem of employee's intention to quit and can cut the cost of company to recruit new comers.

\subsection{Literature Review}

\subsection{Employee Engagement}

To date, there still seem to be an unfixed definition and a generally accepted word for the term employee engagement (Markoz \& Sridevi, 2010). However, previous researchers had come to the same basic as stated by Kahn (1990) by defining employee engagement as "an individual employee's cognitive, emotional and behavioral state directed towards desired organisational outcomes" (Shuck \& Wollard, 2010). Engaged employees will demonstrate emotional and psychological connection to their working environment (Wagner and Harter, 2006; Kahn, 1990).

Engagement can also lead to an increase in internal motivation, mindfulness, individual creativity, and ethical behavior as well as increase in efforts to do beyond given tasks. They will also become more productive and happier as they are able to work within a comfortable condition (Robertson-Smith \& Markwick, 2009). Organisation can measure the outcomes of engagement practice by looking at the increase in customer loyalty, reduce in employee turnover, and increase in employee productivity as well as financial success (Robertson-Smith \& Markwick, 2009). This statement was consistent with the findings by Harter et al. (2002) in the Meta analysis on 7400 business units, as they found existence of relationship between employee engagement with various outcomes, such as customer satisfaction, productivity, profit and employee turnover that subsequently influenced business success.

\subsection{Supportive Work Environment}

Working environment was determined as one of the critical factors that established the level of employee engagement within an organisation. Previous studies done by Miles (2001), Harter et al. (2002), Holbeche and Springett (2003), May et al. (2004) and Rich et al. (2010) showed that several aspects of the working environment may lead to employee engagement outcomes. Deci and Ryan (1987) demonstrated that any management function that practices a supportive working environment will normally present their care and concern for employees' needs and their feelings by providing them with positive responses and encouraging them to voice out their needs in order to boost their skills and ability to be an employee with problem solving traits. Thus, a harmonious and adaptable working environment that enables employees to focus on their work and interpersonal development is classified to have a high relationship to employee engagement. (Anitha, 2013) 
A supportive working environment can act as a holistic measure that can increase the level of employee engagement. From the Gallup's data surveyed, it is suggested that there is no metric that measures more on diversity in human behavior than its environment. Working environment can also be determined as all the important thing that is reflect on how we think of our lives and experience it (Rath\& Harter, 2010). Therefore, working environment becomes a critical point to measure the organisation's influence towards its employees.

Supportive environment that enables to stimulate and maintain the relevant elements are develop based on concepts like friendships, cooperation, support and trust (Kahn, 1990). To describe the current condition of a supportive working environment, employees will be asked about friendships, cooperation, support and trust. In fact, employees who do not acquire these criteria in their working relationships will feel alone, disconnected to others, isolated and stressful. Relationships never built in any unsafe workplace or when employees feel threatened by any threat and they have to be hypocrite instead of being their selves (Kahn, 1990). By feeling connected to work, it will significantly reflect the employee's experience upon their work, thus increasing employees' engagement.

\subsection{Team and Co-worker Relationship}

Team and co-worker relationship is another aspect that can be considered as part of the factors which determines employee engagement. According to Kahn (1990) he found that supportive and trusting relationships among employees can offer high employee engagement level as they are built on the basis of a harmonious and concrete relationship traits.

Supportive team members will help every member of the team to explore new things and give full support in hard condition and any difficulty (Kahn, 1990). This statement also supported by May et al. (2004) who found that relationships build in the working place gives significant impact on being meaningful which is an important part of any engagement component. According to Locke and Taylor (1990), employee who possess positive interpersonal relationship and interaction with members at the work place, will experience a great level of meaning towards their work as well as becoming engaging team members. In short, when employees are able to build good relationships with the members within an organisation, their work engagement is considered to be at high level (Anitha, 2013).

\subsection{Organization Well-being}

Organisation well-being is an important measurement of determination for employee engagement (Anitha, 2013). From Gallup's data, it is suggested that there is no metric that captures more variance in human behavior than well-being. Rath and Harter (2010) defined well-being as all things which are crucial to influence about what people think and experience in their lives. In other words, well-being is considered the most essential measure to capture the influences of an organisation towards their employees. (Anitha, 2013)

Towers Perrin Talent Report (2003) also found that the importance of well-being is investigated by many scholars as the most important determinant of engagement as they impacted to senior management level of interest toward their employee well-being.

\subsection{Underpinning Theory}


In side of the theoretical foundation and linkage with Kahn's (1990) engagement concept, motivational theories developed be Abraham Maslow (1970) is much closer to Kahn's concept. It is known that Maslow hierarchy of needs provides a clear and better understanding of a conceptual framework. According to Maslow, it is important to fulfil the basic human needs as well as building a context to the conceptualization of employee engagement. However, in this study, Social Exchange Theory (SET) and Leader Member Exchange and Team Member Exchange (LMX-TMX) theories will be used in this study since both of these theories does fully explain the relationship of each and every variable involved.

\subsection{The Social Exchange Theory}

The social exchange theory (which is also known as SET) is becoming the most matched and accepted theory used in current researches and studies of employee engagement. According to Saks (2006) SET is among the toughest and solid theoretical support to explain employee engagement.

The critical point on the SET is that people make social decisions due to the perceived costs and benefits (Cropanzano \& Mitchell, 2005). The human made evaluation of the social relationships by determine the advantages and benefit that they will get through the relationship (Ethugala, 2011). Saks (2006) also mentioned that the best way for employees to repay their firm's kindness is by presenting high level of engagement. In short, SET gives a clear view on a theoretical explanation as why employees option to choose to put oneself either more or less engaged in their job and within the organisation. The conditions of engagement in both of Kahn's (1990) can be viewed as economic and socio emotional exchange resources. This brings to the fact that, when employees are well equipped with these resources from their firm, they will tend to repay the firm by showing high levels of engagement.

\subsection{Leader-Member Exchange (LMX) Theory}

Leader-member exchange (LMX) theory can be used at an individual level. This is closely related to workplace relationship among employees. Moreover, workplace relationship has a positive relation with team-member exchange (TMX), so that, they form a linkage between both of the LMX-TMX theory. Seers (1989) defined LMX-TMX as the quality of relationship between a person and an employee with other members of the team.

There are many researches which are being conducted in order to understand the applications of leader member exchange (LMX) theory over the last 25 years (Graen \& Uhl-Bien, 1995). Regarding LMX theory, the theorists concentrated more on differentiating the exchange existence in relationships for a leader to develop and maintain their relationship with their subordinates by working together as a team (Dansereau et al., 1975).

Sparrowe and Liden (1997) also added that interpersonal relationships among leaders, subordinates, and coworkers are interconnected with one another to form a large social system that operates as a team and organisation. According to Graen and Uhl-Bien (1995) they are very much looking into system perspective, they have asked for more researchers to conduct researches in order to develop better understanding of how the LMX dyadic relationships can affect employees' work attitudes and behaviors in larger teams within an organisation.

This is due to the fact that not only LMX gives influence to the dyadic relationship among leaders and 
team members, but it may also have an influence towards other exchange relationships inside a larger organisation. In relation to that, LMX might have an affect towards team member exchange (TMX). Furthermore, high-quality of LMX relationship can create a comfortable working environment and thus result in effective communication as a shared identity or having common values. This will be a platform for employees to reduce the gap between them and experience a strong emotional attachment with each other in their workforce as well as to enhance friendship formation at the work place (Ellemers, et al., 2004).

As a summary of this theory, the LMX-TMX theories are very much related to each other and posses a strong impact to the key determinant of employee engagement. This theory can support the determinant of work environment, team and co-worker relationship as well as an organisation's well-being.

\subsection{Framework}

The conceptual framework for this study is designed as below:

Figure 1: A proposed conceptual framework

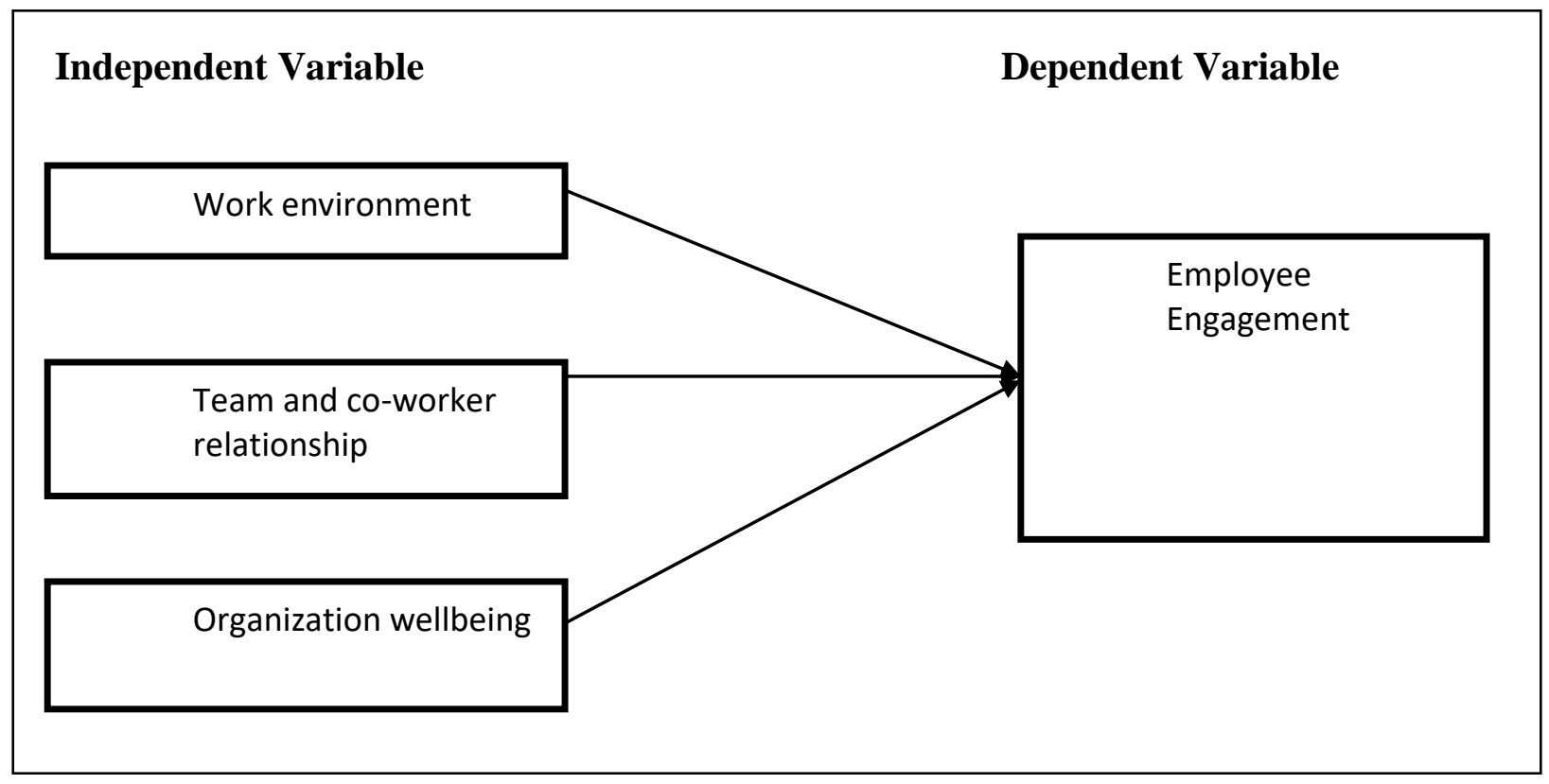

\subsection{List of Propositions}

Even though there are a lot of factors that have been acknowledged as important determinants of employee engagement, this study aims to reach the objective as to provide a critical antecedent of employee engagement in terms of work environment, team and co-worker relationship, and organisational well-being. Thus, the hypotheses are as follows:

H1 : Work environment is significantly related to employee engagement

$\mathrm{H} 2$ : Team and co-worker relationship is significantly related to employee engagement 
H3 : Organisation well-being is significantly related to employee engagement

\subsection{METHODOLOGY}

This research is designed as a quantitative study approach. It is a hypothetical deductive research as it is aimed to generate knowledge and determine the relationship between the independent and dependent variables of employee engagement. The research used a cross-sectional design because it will be conducted in a short period of time.

Simple random sampling is being used to select the employees from middle and lower managerial levels from four banks in Kuala Lumpur. A total of 400 questionnaires will be distributed in three weeks. The population for this research is Banking Industry employees in the areas around Kuala Lumpur, Malaysia. Samples will be selected from two different levels of employees which are middle managerial level consists of all units and department assistant managers and bank officers. For lower managerial level, front line employees at clerical level will be the targeted sample for this research in four banks. The banks involved in this study are Citibank, Maybank, CIMB and Bank Muamalat. All questionnaires will go through the organisation's human resource department. The targeted sample is 400 which consisting 100 questionnaire for each bank.

\subsection{IMPLICATION AND RECOMMENDATION FOR FUTURE RESEARCH}

Key determinants of employee engagement in this paper can promote a healthy working environment which can reflect on the social outlook created by employers. Employees can enjoy considerable attention from the key determinants that is being addressed in this study. In regards with this, managers can generate their confidence level to face with their subordinate and engaged them in organisational development. Adequate time should be considered for setting the objective and to ensure each and every employee gain a clear understanding of the firm's expectations for their achievement. Engaged employees will be more optimistic and productive, thus increasing the organisational performance as a whole.

This research should extend the discussions on the importance of all three determinants towards increasing employees' engagement. Future researches recommended were also furthering this study into investigating the impact on the mentioned variables to employee engagement as well as employee performance in various organisation to gain in-depth knowledge about employee engagement.

\subsection{CONCLUSION}

There are a rising number of researches in employee engagement. However, most of the studies were being conducted by practitioners compared to academic researchers. This is due to much of what has been written about employee engagement that comes from the practitioner literature and consulting firms. There is a surprising dearth of research on employee engagement in the academic literature (Robinson et al., 2004). So there is a critical need for future research to study further about employee engagement.

As mentioned above, many previous researches have provided the evidence that employee engagement is a crucial element to determine the organisation's success. The three independent variables (work 
environment, team and co-worker relationship, and organization well-being) act as antecedents to employee engagement which are chosen in this study based on the emotional state of employee engagement proposed by Kahn (1990). This is also supported by previous research conducted by Saks (2006), stating that although there is little empirical research on the factors that predict employee engagement, however, it is possible to identify a number of potential antecedents from Kahn's (1990) and Maslach et al.'s (2001) model. Shuck and Wollard (2010) also stated that employee engagement can be defined in an emergent and working condition as a positive cognitive, emotional, and behavioral state directed toward organisational outcomes.

In addition, engagement issue is always discussed in behavioral state instead of cognitive and emotional states of engagement (Shuck \& Wollard,2010). Thus, this research is designed to study in emotional states of engagement in term of the relationship among three variables that have impact on employee engagement. By addressing these critical antecedents of employee engagement, this study perhaps will contribute additional knowledge and information to respective organisations in providing a better working environment, build a harmonious and friendly team and construct coworker relationship and last but not least, to put an organisational well-being as an essential element to enhance employee engagement. To engage employees, these initiatives can be applied within the organisation instead of just focusing on monetary initiative like reward and recognition, followed by bonus and salary increment per say.

\section{REFERENCES}

Anitha, J. 2013.Determinants of employee engagement and their impact on employee performance. International Journal of Productivity and Performance Management, 63(3), 308-323.

Deci, E.L.,\&Ryan, R.M. 1987. The support of autonomy and the control of behavior.Journal of Personality and Social Psychology, 53(6), 1024-1037.

Gallup 2002.The high cost of disengaged employees.Gallup Business Journal, 15, available at: http://businessjournal.gallup.com/content/247/the-high-cost-ofdisengagedemployees.

Harter, J.K., Schmidt, F.L.,\& Keyes, C.L. 2002. Well-being in the workplace and its relationship to business outcomes: A review of the Gallup studies.The Positive Person and the Good Life, American Psychological Association, Washington: Flourising Press.

Hewitt Associates LLC. 2004. Research brief: Employee engagement higher at double-digit growth companies. Available at: www.hewitt.com (accessed 21 August 2014).

Holbeche, L.,\&Springett, N. 2003. In search of meaning in the workplace. Horsham, Roffey Park Institute, ISBN: 0907416527.

Kahn, W.A. 1990. Psychological conditions of personal engagement and disengagement at work. Academy of Management Journal, 33(4), 692-724.

Kular, S., Gatenby, M., Rees, C., Soane, E. and Truss, K. 2008, "Employee engagement: a literature review", available at:

http://eprints.kingston.ac.uk/4192/1/19wempen.pdf

Macey, W.H., \& Schneider, B. 2008. The meaning of employee engagement. Industrial andOrganizational Psychology, 1(1), 3-30.

Macey, W.H., Schneider, B., Barbera, K.M., \& Young, S.A. 2009. Employee engagement: Tools for analysis, practice, and competitive advantage. Malden, WA:Wiley-Blackwell.

Maslach, C., Schaufelli, W.B., \&Leiter, M.P. 2001. Job burnout. Annual Review of Psychology, 52(1), 397-422.

May, D.R., Gilson, R.L., \& Harter, L.M. 2004. The psychological conditions of meaningfulness, safety and availability and the engagement of the human spirit at work.Journal of Occupational and 
Organisational Psychology, 77(1),11-37.

Miles, R.H. 2001. Beyond the age of Dilbert: Accelerating corporate transformations by rapidly engaging all employees. Organisational Dynamics, 29(4), 313-321.

Mone, E.M., \& London, M. 2010. Employee engagement through effective performancemanagement: A practical guide for managers. New York, NY:Routledge.

Rath, T., \& Harter, J.K. 2010.Wellbeing: The five essential elements. New York, NY: Gallup Press.

Rhoades, L. and Eisenberger, R. 2002, "Perceived organizational support: a review of the literature", Journal of Applied Psychology, Vol. 87, pp. 698-714

Rich, B.L., Lepine, J.A., \& Crawford, E.R. 2010. Job engagement: Antecedents and effects on job performance. Academy of Management Journal, 53(3), 617-635.

Robinson D., Perryman S., and Hayday S. 2004. The Drivers of Employee Engagement Report 408, Institute for Employment Studies, UK

Saks, A.M., \&Rotman, J.L. 2006. Antecedents and consequences of employee engagement.Journal of Managerial Psychology, 21(7), 600-619.

Shuck, B., \& Wollard, K. 2010. Employee engagement \& HRD: A seminal review of the founda-tions. Human Resource Development Review, 9(1), 89-110.

Towers Perrin Talent Report. 2003. Working today: Understanding what drives employee engagement.Availableat:www.towersperrin.com/hrservices/webcache/towers/United_States/publ ications/Reports/Talent_Report_2003/Talent_2003.pdf (accessed 2 July 2014).

Van Veldhoven, M., De Jonge, J., Broersen, J. P. J., Kompier, M., \& Meijman, T. 2002. Specific relations between psychosocial job conditions and job-related stress: A three-level analytic approach.Work and Stress, 16, 207-228

Wagner, R. and Harter, J.K. 2006,12: The Great Elements of Managing, Vol. 1, The Gallup Organization, Washington, DC

Welch, M. 2011. The evolution of the employee engagement concept: Communication implications. Corporate Communications: An International Journal,16(4), 328-346. 
